\title{
INFLUENCE OF HEAT TRANSFERRING MEDIA ON DURABILITY OF THERMALLY MODIFIED WOOD
}

\author{
Olov Karlsson, ${ }^{\mathrm{a}, *}$ Ekaterina Sidorova, ${ }^{\mathrm{b}}$ and Tom Morén ${ }^{\mathrm{a}}$ \\ Studies on the durability and dimensional stability of a series of \\ hardwoods and softwoods after thermal modification in vegetable oils \\ and in steam atmospheres have been performed. Mass loss after \\ exposure to Coniophora puteana (BAM Ebw.15) for 16 weeks was very \\ low for European birch, European aspen, Norway spruce, and Scots pine \\ thermally modified in a linseed oil product with preservative (for 1 hour at \\ $200{ }^{\circ} \mathrm{C}$ ). Fairly low mass losses were obtained for wood thermally \\ modified in linseed-, tung- and rapeseed oil, and losses were related to \\ the wood species. Low mass loss during rot test was also found for \\ Norway spruce and Scots pine modified in saturated steam at $180{ }^{\circ} \mathrm{C}$. \\ Water absorption of pine and aspen was reduced by the thermal \\ treatments and the extent of reduction was dependent on wood species \\ and thermal modification method. Thermally modified aspen was stable \\ during cycling climate tests, whereas pine showed considerable cracking \\ when modified under superheated steam conditions (Thermo D). At \\ lower modification temperature $\left(180{ }^{\circ} \mathrm{C}\right)$ an increase in mass after \\ modification in rapeseed oil of spruce, aspen and sapwood as well as \\ heartwood of pine was observed, whereas at high temperature $\left(240{ }^{\circ} \mathrm{C}\right)$ \\ a mass loss could be found. Oil absorption in room tempered oil after \\ thermal modification in oil was high for the more permeable aspen and \\ pine (sapwood).
}

Keywords: Oil; Thermal modification; Softwood; Hardwood; Durability; Stability; Cycling test

Contact information: a: Division of Wood Physics, Campus Skellefteå, Luleå University of Technology, S93187 Skellefteå, Sweden; b: SP Technical Research Institute of Sweden, Drottning Kristinas väg 67, S11486 Stockholm, Sweden; *Corresponding author:olov.karlsson@ltu.se.

\section{INTRODUCTION}

In a world of increasing environmental and health awareness the development of sustainable processes that could substitute for the traditional ones and use less environmentally unfriendly wood preservatives is of high interest. Thermal modification of wood is known as a process that enhances wood properties by reducing moisture absorption, improving dimensional stability, and increasing biological durability (Tiemann 1915; Stamm 1964; Burmester 1973; Giebeler 1983). In recent years the heat treatment industrial processes have been developed successfully in Europe. The Finnish Thermowood process (Syrjänen and Kangas 2000; Mayes and Oksanen 2002) developed by VTT (Technical Research Centre of Finland) in cooperation with some Finnish universities and industrial partners has been the dominating one and uses superheated steam as a heat transferring and oxygen precluding medium. A fairly new process provided by the Danish company WTT that uses saturated steam is under development 
(Ohnesorge et al. 2009; Dagbro et al. 2010). Other processes, such as the Dutch PlatoWood (Boonstra et al. 1998) uses steam, the French Retification process uses nitrogen (Dirol and Guyonnet 1993), and the German OHT-Process uses oil (Rapp and Sailer 2001). Hot oil provides fast and equal heat transfer to the wood and the same conditions all over the whole vessel; oil also serves as a good medium for preventing oxygen to come in contact with wood (Rapp and Sailer 2001). It was found that the hydrophobic properties and resistance against biological attack of wood thermally modified in oil not only benefit from the heat treatment, but also from the outer shell formed by penetration of water-repellent oil into the wood during the process (Wang 2007). Higher weathering resistance during accelerated tests has been observed for oil heat treated Pinus radiata (Dubey 2010). However, the colour resistance to weathering has been reported not to be improved for wood thermally modified in oil (Rapp and Sailer 2001), and special surface treatments and coating systems may be used or developed for such material to be used in outdoor conditions. At the same time nail holding resistance after thermal modification in oil as well as the thermal treatment in gaseous atmosphere is reduced (Mayes and Oksanen 2002; Wang 2007). Finally, thermal modification of wood in oil as well as in steam is not recommended in the structural uses where the strength properties are critical (Mayes and Oksanen 2002; Wang 2007).

In this paper results from studies on the influence of heat transferring media on a series of properties on modified wood will be presented. It has been of particular interest to study how thermally modified wood would cope with conditions similar to those prevailing in out-door conditions in northern Scandinavia, especially at exposed sites such as shingles and shakes on roof and bargeboard. In this context, Mayes and Oksanen (2002) have listed a number of recommended out-door products of Thermowood-D like cladding, garden furniture, and so on. The study has been focused into Scots pine, Norway spruce, and European aspen. Scots pine is the dominant wood species used for thermally modified wood products, and thermal modification in vegetable oils could enhance its dimensional stability during weathering. Norway spruce is seldom used in products where durability is a critical factor due to low permeability in pressurized impregnation processes; however, such property might be an advantage when dimensional stability of thermally modified is concerned under strong weathering conditions. European aspen has a low market share but can find application as shingles or shakes at roofs of churches in Nordic countries and durability may be largely improved by thermal modification.

Thus, studies on durability of a series of hardwoods and softwoods after thermal modification in vegetable oils have been performed, comparing with results from thermal modifications in steam atmospheres. Durability here is related to degradation of wood by brown rot fungi but also to crack formation and colour changes during cycling conditions. In this respect the influence of modification conditions and wood species on absorption of vegetable oils during thermal modification and subsequent soaking at room temperature has been investigated. In addition, properties of thermally modified wood may also be influenced by the choice of oil as well as by dissolving additives with various properties (UV-protection, preservatives) into the oil. 


\section{EXPERIMENTAL}

\section{Materials}

The following commercially available oils were used in thermal modification experiments: rapeseed oil (8\% saturated fatty acids, monounsaturated fatty acids $62 \%$ and other unsaturated fatty acids $30 \%$ and $6 \mathrm{mg}$ cholesterol), boiled linseed oil, modified linseed oil with wood preservatives ( $0.6 \%$ propiconazole, $0.3 \%$ IPBC), and tung (Chinese) oil (100\%).

Wood species used were from European ash (Fraxinus excelsior L.), European aspen (Populus tremula L.), European beech (Fagus sylvatica L.), European birch (Betula pubescens Ehrh.), European larch (Larix decidua Mill.), European oak (Quercus robur L.), Scots pine (Pinus sylvestris L.), and Norway spruce (Picea abies (L.) Karst). In the case of pine, wood from boards containing both sapwood and heartwood as well as from boards of pine heartwood and boards of pine sapwood tissues were studied (see Table 1).

\section{Thermal Modification (TM)}

Totally five thermal modification procedures were performed. Two were performed in the presence of steam and three in the presence of vegetable oils.

\section{Thermal modification in superheated steam}

Thermal modification in superheated steam was performed on wood samples from aspen, ash, beech, pine (including sapwood and heartwood), and spruce (Table 1). The samples were thermally modified according to Thermo-D quality. Letter D denotes durability and means that wood treated into this class meets the requirements set in use class 3 (EN 335-1).

The procedure for Thermo-D could be described as follows: A period of heat up and high temperature kiln drying is followed by an increase in temperature to $212{ }^{\circ} \mathrm{C}$ for softwoods and $200{ }^{\circ} \mathrm{C}$ for hardwoods, where more intensive thermal modification takes place for 2-3 hours. The cycle is finished after cooling, moisture stabilisation, and final cooling.

\section{Thermal modification in saturated steam}

Beams of pine and spruce $(5000 \times 100 \times 50 \mathrm{~mm})$ were thermally modified at $160{ }^{\circ} \mathrm{C}$ and $180{ }^{\circ} \mathrm{C}$ in saturated steam (Table 1.). The thermal modification process started with a pre-vacuum, followed by heating and drying period to reach temperatures of $160{ }^{\circ} \mathrm{C}$ and $180{ }^{\circ} \mathrm{C}$, where the primary modification of wood occurs over the course of a few hours. Further process details can be found in (Ohnesorge et al. 2009; Dagbro et al. 2010).

For durability test, samples $(150 \times 20 \times 20 \mathrm{~mm})$ from the two wood species and the treatment conditions $\left(160{ }^{\circ} \mathrm{C}\right.$ and $\left.180{ }^{\circ} \mathrm{C}\right)$ were sawn out from the beams (Table 1$)$.

Thermal modification in rapeseed oil for study of oil pick up

Samples of the sizes $150 \times 20 x 20 \mathrm{~mm}$ were dried in oven at $103{ }^{\circ} \mathrm{C}$ before thermal modification. Wood samples (spruce, aspen, pine sapwood, and pine heartwood) were treated by submerging them into an open steel vessel (450x200x140mm with isolated 
walls) containing hot rapeseed oil at treatment temperatures of 180,210 , and $240^{\circ} \mathrm{C}$. For each treatment temperature three treatment periods were performed (30, 60, and 120 minutes). The wooden samples were put in a basket made of steel-net (submerged in the hot oil) to ensure that the wood samples do not come in contact with surrounding air during the experiment. For each time interval and heat treatment temperature five samples of the given wood species; spruce, pine heartwood, pine sapwood, and aspen, were used (table 1).

Two sets of samples were run. In one set thermally modified board was left to cool in the air after the excess of oil had been wiped away with a cloth. In another set the still hot, oily, and thermally modified board was transferred manually directly into a rapeseed oil bath at room temperature for one hour and then excess of oil was wiped away with a cloth.

Thermal modification in rapeseed oil for cycling tests and crack tests

In the second series of experiments dried aspen, ash, beech, spruce, and pine (300x120x10mm) were heated in the vessel containing rapeseed oil for 1 hour at $180{ }^{\circ} \mathrm{C}$. The still hot oily board was allowed to cool in an oil bath for 1 hour, and then the excess of oil was wiped away with a cloth. The samples were then exposed to cycling climate conditions (see Table 1).

Thermal modification in vegetable oils for durability test

In the third series of experiments dried aspen, birch, pine, and spruce with dimensions of $150 \times 20 x 20 \mathrm{~mm}$ were thermally modified in rapeseed oil, linseed oil, linseed oil with preservatives, and tung oil for 1 hour at $200{ }^{\circ} \mathrm{C}$. After thermal treatment the hot oily board were submerged into room tempered oil for 1 hour, and excess of oil was wiped away with a cloth. The room tempered oil used in the experiments was similar to the one used in the preceding thermal treatment.

\section{Properties of Thermally Modified Wood}

Table 1 shows the experimental set-up for the studies on properties of thermally treated wood species.

Oil up take

The relative mass increase $(M)$ after thermal modification was calculated (Eq. 1),

$$
M=\left(m_{2}-m_{1}\right) / m_{1} \times 100(\%)
$$

where $m_{1}$ is the mass before the heat treatment and $m_{2}$ is the mass after the process. A similar type of calculations was used for studies on oil take up during immersing of boards modified in rapeseed oil into the oil at room temperature. In Eq. (1) $m_{1}$ is the mass before the heat treatment and $m_{2}$ is the mass after the oil immersion process. In Table 1 the wood species and tissues used are further described. 
Table 1. Scheme for Test of Properties of Thermally Modified (TM) Wood

\begin{tabular}{|c|c|c|c|c|}
\hline $\begin{array}{l}\text { Wood property } \\
\text { test }\end{array}$ & Treatment & Wood species & $\begin{array}{l}\text { Dimension } \\
(\mathrm{mm})\end{array}$ & $\begin{array}{l}\text { Number of } \\
\text { samples }\end{array}$ \\
\hline \multirow[t]{2}{*}{ Oil pick-up } & TM in rapeseed oil & $\begin{array}{l}\text { Aspen, spruce } \\
\text { and pine }{ }^{a}\end{array}$ & $150 \times 20 \times 20$ & 180 \\
\hline & $\begin{array}{l}\text { TM in rapeseed oil } \\
+ \text { soaking in oil }\end{array}$ & $\begin{array}{l}\text { Aspen, spruce } \\
\text { and pine }\end{array}$ & $150 \times 20 \times 20$ & 180 \\
\hline \multirow[t]{3}{*}{$\begin{array}{l}\text { Water } \\
\text { absorption }\end{array}$} & Untreated. & $\begin{array}{l}\text { Aspen, pine } \\
\text { and spruce }\end{array}$ & $300 \times 120 \times 10$ & 12 \\
\hline & $\begin{array}{l}\text { TM in superheated } \\
\text { steam. }\end{array}$ & $\begin{array}{l}\text { Ash, aspen, beech, } \\
\text { pine and spruce }\end{array}$ & $300 \times 120 \times 10$ & 40 \\
\hline & $\begin{array}{l}\text { TM in rapeseed oil } \\
+ \text { soaking in oil. }\end{array}$ & $\begin{array}{l}\text { Aspen, pine } \\
\text { and spruce }\end{array}$ & $300 \times 120 \times 10$ & 24 \\
\hline \multirow{3}{*}{$\begin{array}{l}\text { Crack forma- } \\
\text { tion and colour } \\
\text { change }\end{array}$} & Untreated & $\begin{array}{l}\text { Aspen, larch, oak, } \\
\text { pine and spruce }\end{array}$ & $300 \times 120 \times 10$ & 80 \\
\hline & $\begin{array}{l}\text { TM in superheated } \\
\text { steam }\end{array}$ & $\begin{array}{l}\text { Ash, aspen, beech, } \\
\text { pine and spruce }\end{array}$ & $300 \times 120 \times 10$ & 80 \\
\hline & $\begin{array}{l}\text { TM in rapeseed oil } \\
+ \text { soaking in oil. }\end{array}$ & $\begin{array}{l}\text { Aspen, pine } \\
\text { and spruce }\end{array}$ & $300 \times 120 \times 10$ & 48 \\
\hline \multirow[t]{3}{*}{ EN 113} & Untreated & $\begin{array}{l}\text { Aspen, birch, pine, } \\
\text { and spruce }\end{array}$ & $150 \times 20 \times 20$ & 16 \\
\hline & $\begin{array}{l}\text { TM in saturated } \\
\text { steam. }\end{array}$ & Pine and spruce & $150 \times 20 \times 20$ & 16 \\
\hline & $\begin{array}{l}\text { TM in linseed oil, } \\
\text { linseed oil with } \\
\text { preservative, rape- } \\
\text { seed oil, tung oil } \\
\text { + soaking in oil. }\end{array}$ & $\begin{array}{l}\text { Aspen, birch, pine, } \\
\text { and spruce }\end{array}$ & $150 \times 20 \times 20$ & 64 \\
\hline
\end{tabular}

a. Individual samples of sapwood and heartwood of pine were used.

Water absorption

Samples from each wood species and treatment (see Table 1) were tested under cycling climate changes. Samples were soaked by submerging room tempered and dried samples in water for 24 hours, then freezing at $-28{ }^{\circ} \mathrm{C}$ for six days. Samples were directly heated by an IR lamp (2000W) at a distance of about $1 \mathrm{~m}$ for 30 minutes, resulting in an 
increase of the surface temperature to $40{ }^{\circ} \mathrm{C}$. In the first cycle the water absorption $(W)$ of the samples was measured and calculated in percentage (Eq. 2),

$$
W=\left(m_{w}-m_{d}\right) / m_{d} \times 100(\%)
$$

where $m_{d}$ is the mass before water soaking and $m_{w}$ is the mass after water soaking.

Visual inspection of cracks and colour

After climate testing, visual inspection of the extent of crack formation of boards was made and was recorded with a digital camera. Treatments and wood species used are described in Table 1. Colour changes of boards before after cycling treatments were recorded with a digital camera and compared by visual inspection with the naked eye (Table 1).

\section{Durability against brown rot fungi}

The decay test with the brown rot fungus Coniophora puteana (BAM Ebw.15) was performed on samples of untreated wood and thermally modified samples (Table 1). For the durability test four samples from each wood species and treatment condition were used. The samples were treated essentially according to the standardized EN 113 decay test; however samples were dried at $50{ }^{\circ} \mathrm{C}$ (instead of $103{ }^{\circ} \mathrm{C}$ ) before treatment with brown rot to reduce exudation of oil (linseed and rapeseed oils). The mass loss of the samples after an incubation time of 16 weeks, expressed as a percentage of the original mass before the decay test was used to estimate the extent of degradation of the materials.

\section{RESULTS AND DISCUSSION}

\section{Thermal Modification in Rapeseed Oil}

Thermal modification in rapeseed oil was performed by immersing small wood boards into a hot oil bath open to air. The boards were dried in an oven before the thermal treatment to facilitate the heat transferring capacity of oil, the uptake of oil into the material, and to promote easier calculation of oil uptake. Data from studies on mass changes (see experimental section) after thermal modification in rapeseed oil are presented in Fig. 1 and Table 2 (although oil uptake was not directly measured, the increase in mass can give a rough estimation on the uptake, especially at the milder modifications).

At $180^{\circ}$, increasing oil absorption with increasing thermal treatment time for all species was observed in our experiments (Fig. 1). According to the data in Fig. 1 and Table 2 the mass increase after modification was related to the type of wood. Rather limited oil uptake (20 to $60 \mathrm{~kg} / \mathrm{m}^{3}$ ) has been observed by modification of spruce or pine in hot linseed oil (Rapp and Sailer 2001). Increase in mass during thermal modification in rapeseed oil was similar to or somewhat higher in pine sapwood than in spruce (Table 2). On the other hand, take-up of oil was higher for aspen than the softwood samples in most cases (Fig. 1 and Table 2). The similar oil absorption of pine sapwood and spruce is somewhat surprising. Pine sapwood is more permeable than spruce due to the presence of 
only small pores in spruce, compared to larger "window" pores in pine that allow a more easy liquid penetration into the pine sapwood (Sehlstedt-Persson et al. 2006). However, a lower density of spruce than pine sapwood may compensate for these anatomical differences when oil absorption is the issue.

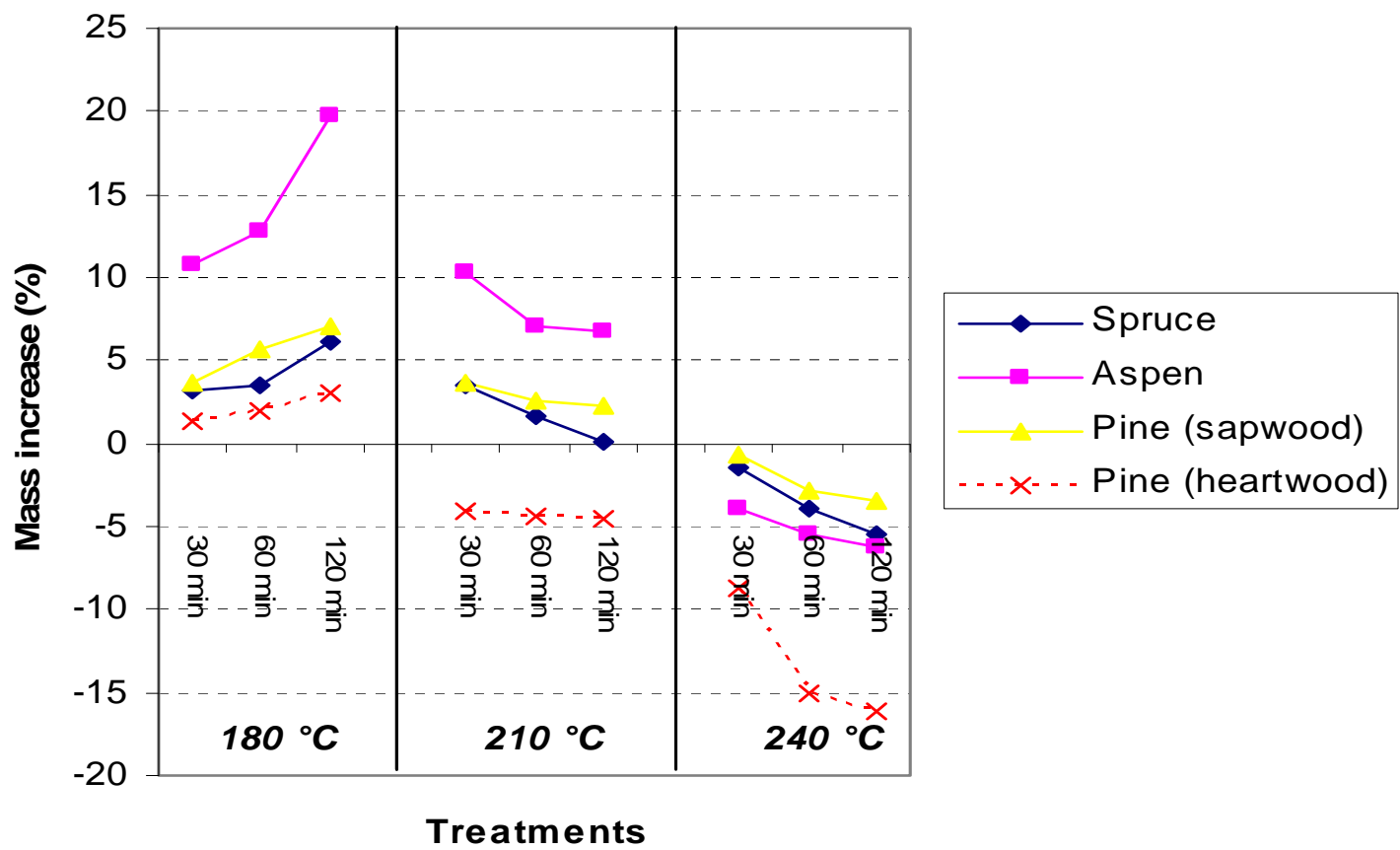

Fig. 1. Mass increase during thermal modification in Rapeseed oil. Effect of modification temperature and period.

Table 2. Mass Increase during Heat Treatment (St. D. = standard deviation).

\begin{tabular}{lcclll}
\hline \multicolumn{2}{l}{ Treatment Condition } & \multicolumn{5}{l}{ Percentage Mass Increase (St. D.) } \\
$\begin{array}{l}\text { Temp. } \\
\left({ }^{\circ} \mathrm{C}\right)\end{array}$ & $\begin{array}{l}\text { Time } \\
(\mathrm{min} .)\end{array}$ & Spruce & $\begin{array}{l}\text { Pine } \\
\text { heartwood }\end{array}$ & $\begin{array}{l}\text { Pine } \\
\text { sapwood }\end{array}$ & Aspen \\
\hline 180 & 30 & $3.19(1.12)$ & $1.39(0,87)$ & $3.61(0.23)$ & $10.84(3.10)$ \\
180 & 60 & $3.47(0.25)$ & $1,98(0.99)$ & $5.72(1.29)$ & $12.80(5.33)$ \\
180 & 120 & $6.18(0.65)$ & $2,99(0.48)$ & $6.99(1.28)$ & $19.79(11.22)$ \\
& & & & & \\
210 & 30 & $3.52(0.87)$ & $-4,03(1.31)$ & $3.76(1.21)$ & $10.27(3.49)$ \\
210 & 60 & $1.66(0.66)$ & $-4,45(1.74)$ & $2.58(0.93)$ & $7.07(0.81)$ \\
210 & 120 & $0,09(1.13)$ & $-4,60(2.28)$ & $2.34(0.41)$ & $6.83(0.40)$ \\
& & & & & \\
240 & 30 & $-1.52(0.35)$ & $-8,72(2.94)$ & $-0.76(0.33)$ & $-3.92(0.93)$ \\
240 & 60 & $-3.88(0.39)$ & $-15,04(4.99)$ & $-2.89(0.74)$ & $-5.50(1.79)$ \\
240 & 120 & $-5.42(0.39)$ & $-16,17(2.17)$ & $-3.43(0.76)$ & $-6.23(7.51)$ \\
\hline
\end{tabular}


The well known brown colour of thermally modified wood started to form during hot oil modification and was not surprisingly stronger for aspen than for the softwood species. The formation of brown coloured wood is related to changes in the chemical composition of wood components such as lignin and hemicelluloses. Formation of volatile gases and acids as well as decrease in hemicellulose content takes place during thermal modification, leading to a decrease in mass of modified wood (Alén et al. 2002; Sivonen et al. 2002; Tjeerdsma and Militz 2005, Dubey 2010). In fact, a reduction in the mass of pine heartwood was observed at $210^{\circ} \mathrm{C}$ probably due to a higher content of native extractives than in sapwood that could be removed or evaporated during a thermal modification process and also due to the low permeability of pine heartwood. The higher permeability for the other modified wood samples is reflected by the initial increase of mass of the samples after 30 minutes of treatment (Fig 1. and Table 2). But as the materials were degraded by further treatment, they also started to decrease in mass (Fig. 1). At $240^{\circ}$ reduction in mass of all species, including the permeable aspen, was observed, and also the mass loss increased with increasing thermal modification period (Fig. 1).

It is thus questionable whether permeability to hot oil is increased at higher modification temperatures. We also know that wood volume shrinks due to degradation and removal of wood components during thermal modification of wood. Micropores have been reported to form during heat modification (Hietala et al. 2002), and as a consequence this could mean that the size of larger pores (lumen) decreases, thereby possibly decreasing the ability of oil to penetrate the wood. Several studies indicate that condensed and dehydrated structures start to be formed at higher modification temperatures (Tjeerdsma et al. 1998; Wikberg and Maunu 2004; Windeisen et al. 2007), and they may influence a deeper penetration into the wood structure.

\section{Absorption of Oil of Thermally Modified Wood at Room Temperature}

Thermal modification in oil may also be used to facilitate a subsequent impregnation in oil with various properties at room temperature and atmospheric pressure. Results from mass increase during thermal treatment and direct cooling in the oil are presented in Fig. 2 and Table 3. Large penetration of oil occurred for all species when the hot modified boards were put in a vessel filled with oil at room temperature, and specimens started to sink after resting in the oil bath. The high absorption is attributed to the formation of reduced pressure inside the wood when the hot oily air is cooled, forcing cool oil to penetrate into the pores of wood (Grenier et al. 2003). Nevertheless, wood species or wood tissue, as well as modification temperature, but not heat modification period had an effect on the oil absorption in the stage of cooling (Fig. 2 and Table 3). Pine sapwood, followed by aspen, had the highest oil pick-up, whereas pine heartwood and spruce had the lowest oil pick-up (Fig. 2 and Table 3). From comparison of Table 2 and 3 we suggest that pick-up of the relatively cool oil was reduced for aspen samples that were thermally modified at $240^{\circ} \mathrm{C}$ (see discussion in latter section above).

Obviously, penetration of oil is a complicated process and dependent on many variables. It could be noted that a lower uptake of oil at lower moisture content in spruce wood has been found when performing oil impregnation using linseed oil without modification by heat (Ulvcrona et al. 2006). 
The results indicate that the extent of oil penetration could be controlled by the choice of wood species and tissue type, as well as conditions during heat modification, followed (or not followed) by soaking in room tempered oil. In this way it should also be possible to use oils with other properties and additives such as UV-protecting chemicals and dyes to further modify properties of the heat modified wood.

Table 3. Mass Increase after Immersing Thermal Modified Wood in Rapeseed Oil at Toom Temperature (St. D. = standard deviation)

\begin{tabular}{lccccc}
\hline \multicolumn{2}{l}{ Treatment Condition } & \multicolumn{4}{c}{ Mass Increase (St. D.) } \\
$\begin{array}{l}\text { Temp. } \\
\left({ }^{\circ} \mathrm{C}\right)\end{array}$ & $\begin{array}{c}\text { Time } \\
(\mathrm{min} .)\end{array}$ & Spruce & $\begin{array}{c}\text { Pine } \\
\text { heartwood }\end{array}$ & $\begin{array}{c}\text { Pine } \\
\text { sapwood }\end{array}$ & Aspen \\
\hline 180 & 30 & $14.99(1.00)$ & $10.87(6.72)$ & $75.15(22.8)$ & $78.53(7.61)$ \\
180 & 60 & $13.98(4.80)$ & $9.65(3.25)$ & $77.95(8.67)$ & $69.21(7.71)$ \\
180 & 120 & $13.80(1.14)$ & $7.89(1.72)$ & $77.99(13.61)$ & $74.98(7.34)$ \\
& & & & & \\
210 & 30 & $20.61(4.64)$ & $17.43(12.95)$ & $98.54(10.09)$ & $84.58(8.49)$ \\
210 & 60 & $15.27(3.65)$ & $11.55(5.45)$ & $84.33(7.57)$ & $88.55(3.89)$ \\
210 & 120 & $17.24(2.35)$ & $14.18(7.49)$ & $91.93(17.3)$ & $75.25(25.66)$ \\
& & & & & \\
240 & 30 & $10.14(3.87)$ & $5.67(5.12)$ & $94.19(13.31)$ & $48.64(29.71)$ \\
240 & 60 & $7.81(0.80)$ & $3.82(5.15)$ & $77.10(8.37)$ & $58.09(19.06)$ \\
240 & 120 & $11.69(0.88)$ & $3.99(3.37)$ & $77.29(21.53)$ & $52.63(25.09)$ \\
\hline
\end{tabular}

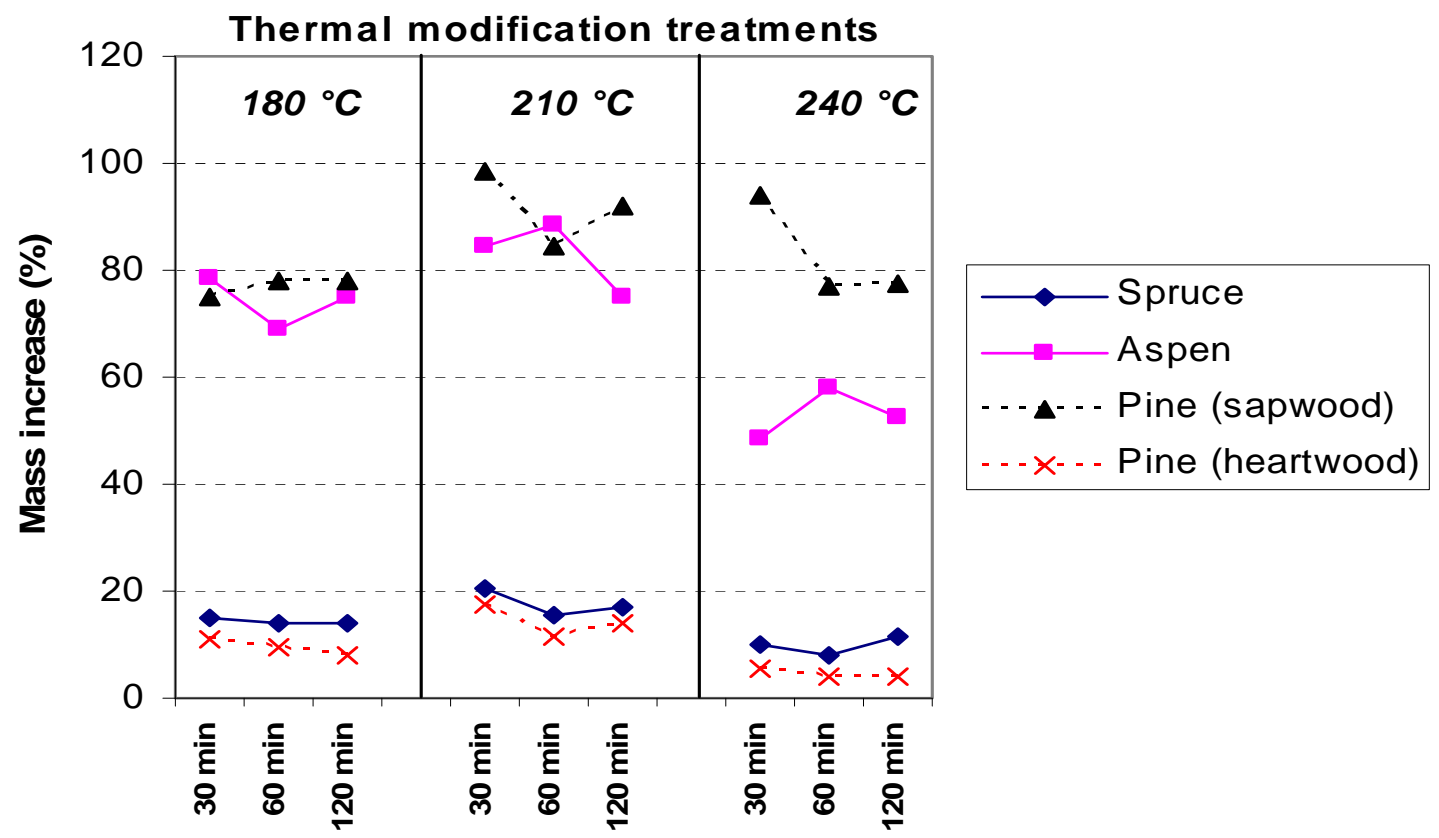

Fig. 2. Mass increase after immersing thermal modified wood in rapeseed oil at room temperature. Effect of modification temperature and period. 


\section{Water Absorption and Dimensional Stability under Cyclic Conditions}

A durable material can be defined as one in which important properties are conserved in the face of various outer stresses such as from a cycling temperature, freezing, raining, biological deterioration, and so on. Cycling climatic changes can create large stresses on the wood structure with possible formation of cracks that could influence other aspects of durability such as biological and chemical deterioration.

We have performed cycling tests where wood was soaked in water, then frozen, and subsequently heated with an IR-lamp (mimicking conditions during the late-winterearly-spring in northern Scandinavia). Dimensional stability of wood thermally modified in superheated steam and also from treatment in hot oil was studied. Results from water absorption from the first cycle are presented in Table 4 and Fig. 3.

Table 4. Water Absorption of Wood and Wood Thermally Modified (TM) in Oil or Superheated Steam ( $M$-percentage mass increase, St. D. -standard deviation).

Type of Treatments

\begin{tabular}{lccc} 
& Aspen & Pine & Spruce \\
\hline Untreated & $27.7(4.1)$ & $36.8(1.7)$ & $30.8(3.1)$ \\
TM superheated steam & $18.1(2.8)$ & $28.2(7.7)$ & $16.3(3.1)$ \\
TM rapeseed oil & $19.7(3.2)$ & $12.0(2.4)$ & $28.7(5.9)$ \\
\hline
\end{tabular}

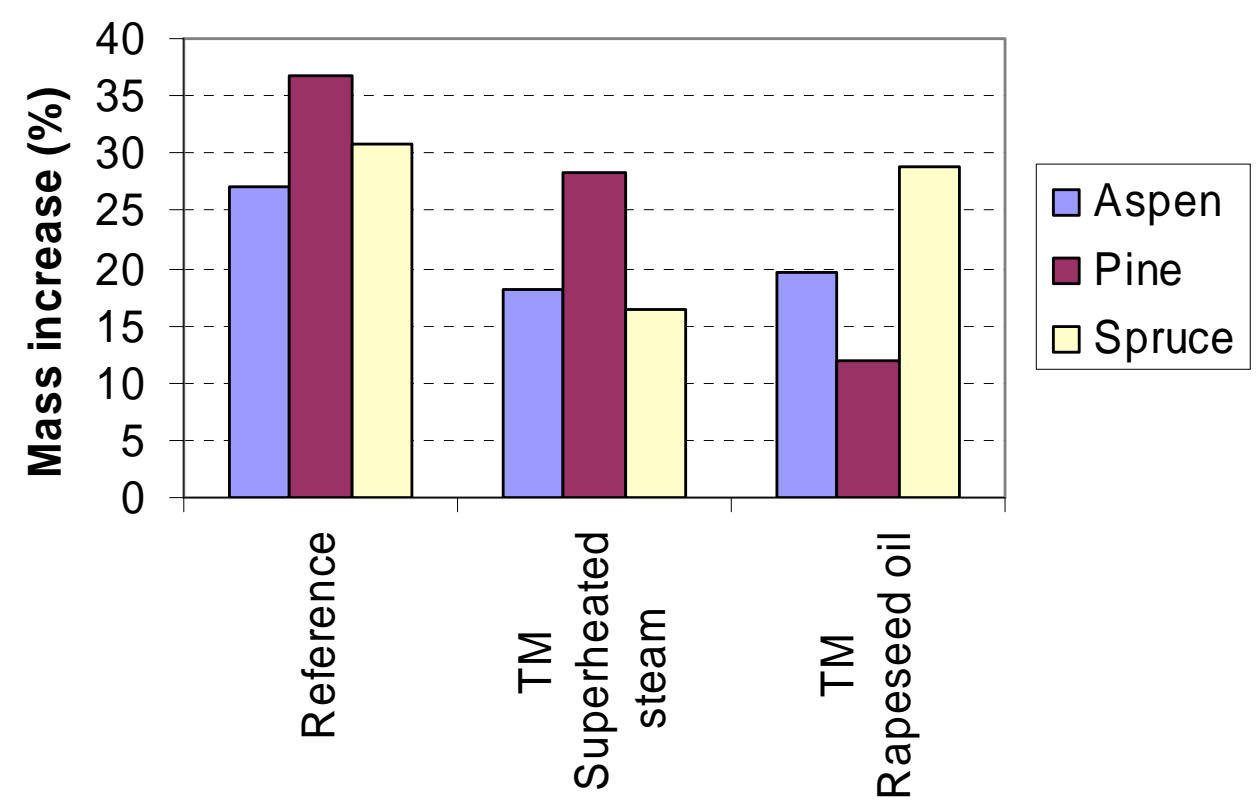

Fig. 3. Water absorption of wood and wood thermally modified (TM) in oil or superheated steam (Thermo D). 
As a comparison, untreated samples from softwood and hardwood species were used in the study (Table 4, Fig. 3). Untreated spruce absorbed less water than pine (Table 4). It could be mentioned that spruce was found to absorb less capillary water than birch and pine (Sehlstedt-Persson et al. 2006). Also aspen absorbed less water than pine (Table 4). This is quite different compared to what was observed during soaking of hot thermally modified wood in room tempered oil (see Table 2). Contrary to oil, the uptake of water is, however, complicated by absorption of moisture into the cell wall and simultaneous swelling of the material.

Water absorption of spruce and aspen samples thermally modified in superheated steam conditions was lower than for the corresponding untreated wood samples (Table 4). This is in line with the reported reduction in hygroscopicity and reduced absorption of water by the wood cell wall after thermal modification under superheated steam conditions (Syrjänen and Kangas 2000; Mayes and Oksanen 2002). A moderate decrease in absorption of water was observed upon thermal modification of pine in superheated steam. In addition, absorption of capillary water by birch and spruce has been reported to decrease during thermal modification but increased when pine was modified at $170{ }^{\circ} \mathrm{C}$ (Sehlstedt-Persson et al. 2006). Furthermore, water absorption tests of a few other hardwoods thermally modified with superheated steam were performed. Thermally modified beech had the lowest water absorption among all examined wood species (ca $10 \%$ ), which may be explained by its comparatively high density and rather narrow vessels. Similar but higher water absorption (ca. 18\%) was obtained for ash. Ash is ringporous with rather wide vessels, and aspen is diffuse-porous with rather narrow vessels but has lower density than the other hardwoods.

From what has been discussed above, it is reasonable that thermal modification of spruce and pine in superheated steam results in a decrease of absorption of water during soaking (Table 4). The importance of resistance to water absorption by penetrated oil in the wood after thermal modification has been reported (Wang and Cooper 2005). A further reduction of water absorbance was observed for pine but surprisingly not for aspen when rapeseed oil was used as heat transferring medium instead of superheated steam. For pine the decreased water absorption seems to be mostly due to high oil pick up during thermal modification in oil followed by soaking in oil (see Table 2 and Fig. 1), since the modifying conditions was milder $\left(180{ }^{\circ} \mathrm{C}\right)$ than during treatment in superheated steam $\left(212{ }^{\circ} \mathrm{C}\right)$. Interestingly, for spruce even higher water absorption was observed when thermal modification was performed in rapeseed oil instead of superheated steam (Table 4). In this case the oil absorption was low as well as modification extent.

The extent of oil absorption as well as the extent of modification of the wood could only partly explain the results on water absorption we obtained after thermal modification in oil. For example it is difficult to find conclusive reasons as to why thermal modification of spruce in oil led to a material with, on average, only slightly lower water absorption than before thermal modification (Table 4). As mentioned above, penetration of wood by liquids depends on many factors. It has, for example, been found that absorption of capillary water by sapwood of pine was higher at a modification temperature at $170{ }^{\circ} \mathrm{C}$ than when dried under mild conditions or thermally modified at $200{ }^{\circ} \mathrm{C}$ (Sehlstedt-Persson et al. 2006). 
Almost no cracking of the thermally modified samples could be observed by visual inspection of the boards (a small tendency to formation cracks in pine was observed). After cycling experiments cracking was observed in the case of pine thermally modified in superheated steam (Fig 4). As can be seen in Fig. 4, cracks propagated starting at the button. Only small tendencies or no crack formation was observed for other wood species (spruce, beech, ash, and aspen). Some exudation of oil was observed with pine but not with spruce after the cycling treatment. Colour was fairly stable after soaking but darkened somewhat even though coloured compounds were extracted from the thermally modified board during the water soaking. The reason for this behaviour is not known but may be related to removal of soluble acids from the material, leading to an increase of the $\mathrm{pH}$ of the board. This will be further studied.

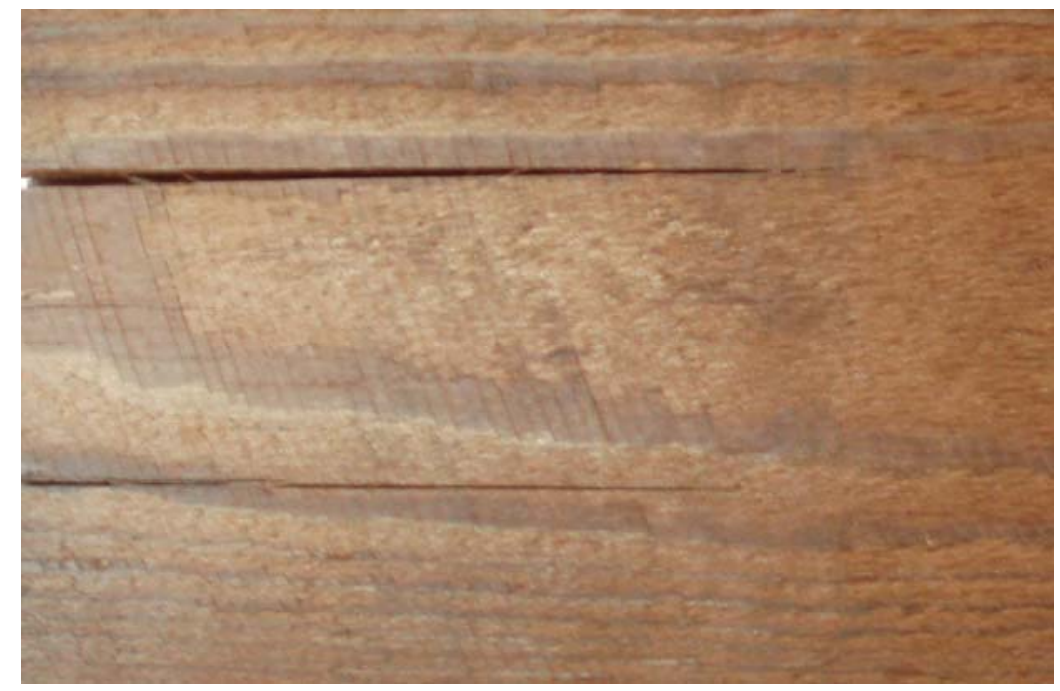

Fig. 4. Crack formation in thermally modified pine (superheated steam) after cycling

A peculiar effect on colour appearance of the boards was observed after the cycling test of oak (Fig. 5). Bands with other colours could be observed after cycling, probably related to so-called sticker marks from initial drying of the boards. Marks from stickers were also found on samples from spruce and larch.

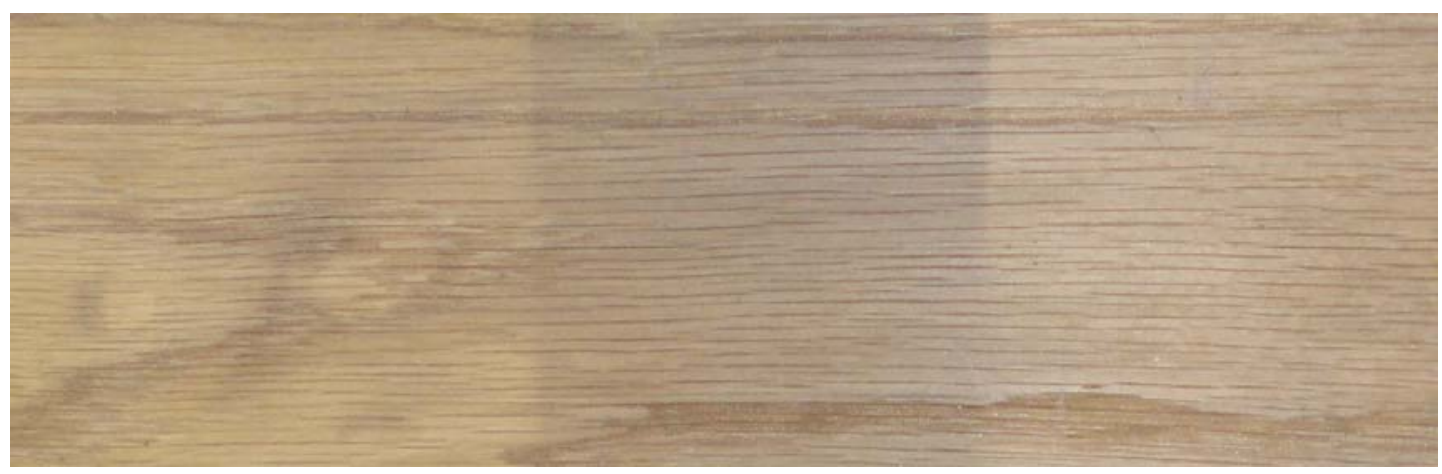

Fig. 5. Formation of areas with other colour during cycling test of oak 
Such marks have been reported to become visible after thermal treatment (Guner 2009). The reason for this may be related to enrichment of water-soluble extractives such as sugars near the surface during so-called capillary phase of the drying of green wood (Theander et al. 1993; Sehlstedt-Persson 1995).

\section{Durability against Brown Rot Fungi}

Biological deterioration of wood can take place by rot fungi such as brown rot, white rot, and soft rot. Although their activity varies, for example in different soil types, brown rot is the dominant degrading type of fungi and was used in accelerated tests of thermally modified wood essentially according to EN 113.

Mass loss from thermal modification in steam and in various vegetable oils was studied (for used wood species and treatments see Table 1). It should be mentioned that thermal modification temperature under steam conditions is lower than in superheated steam.

Durability of pine against Coniophora puteana (BAM Ebw.15) increased when samples were thermally modified in saturated steam; especially at $180{ }^{\circ} \mathrm{C}$ a dramatic increase could be seen for both pine and spruce (Fig. 6). From studies on colour formation, thermal modification in saturated steam around $170-180{ }^{\circ} \mathrm{C}$ gave similar colour as treatment in superheated steam at $212{ }^{\circ} \mathrm{C}$ (Thermo-D) (Dagbro et al. 2010). The lower deviation in data indicates that the modification became more uniform at the higher temperature. Higher but similar mass losses obtained after treatment with Poria Placenta and Gloeophyllum Trabeum has been observed (Ohnesorge et al. 2009).

When wood was thermally modified in vegetable oils for 1 hour at $200{ }^{\circ} \mathrm{C}$ also an improvement in mass loss after the rot test was observed. By inspection of data in Table 5 and Fig. 6 it can be concluded that mass loss after the rot test is related to wood specie and type of vegetable oil without preservatives used during the thermal modification. Pine and birch were found to be more durable than spruce. Furthermore, mass loss of aspen by thermal modification in tung oil was lower than for spruce. This could also be true during thermal modification in rapeseed, but evaluation of durability was obscured by exudation of oil that took place from board samples of aspen but not with spruce (Fig. 6).

Such behaviour is not surprising, since penetration by rapeseed oil during thermal modification of aspen was larger than in spruce (see Fig. 1). A product consisting of a linseed oil with preservatives improved mass losses for spruce and aspen, and only small mass losses were found for the wood species after exposure to brown rot fungus (Table 1). This means that the linseed product is still active after thermal treatment at $200{ }^{\circ} \mathrm{C}$, and subsequent soaking in oil even though preservatives like propiconazole and IPBC are not considered to be thermally stable.

Based on the performed experiments good durability against brown rot fungi Coniophora puteana (BAM Ebw.15) of wood thermally modified in both vegetable oils and saturated steam was obtained. Fairly good durability was also obtained for aspen, whereas mass loss after the rot test for spruce was rather significant. In order to increase its stability, modification at higher temperatures is probably necessary, but another possibility could be to perform soaking in oil with preservatives right after heat modification in oil (Table 6 and Fig. 5). 
Table 5. Mass Loss After Exposure of Wood and Thermally Modified (TM) Wood to Coniophora puteana (*exudation of oil was observed in test); S160, S180 (TM in Saturated Steam at $160{ }^{\circ} \mathrm{C}$ and $180{ }^{\circ} \mathrm{C}$, respectively), LO (TM in linseed oil and soaking in oil), LO add (TM in linseed oil including preservative and soaking in oil), TO (TM in Tung oil and soaking in oil), and RO (TM in rapeseed oil and soaking in oil). (St. D. = standard deviation)

\begin{tabular}{lcccc} 
Modification treatment & \multicolumn{3}{c}{ Mass Percentage Loss (St. D.) } \\
& Aspen & Birch & Pine & Spruce \\
\hline Untreated & $44.3(3.9)$ & $52.3(2.7)$ & $35.6(5.3)$ & $37,9(8.4)$ \\
Saturated steam $160^{\circ} \mathrm{C}$ & - & - & $13.1(9.2)$ & $35.6(5.3)$ \\
Saturated steam $180^{\circ} \mathrm{C}$ & - & - & $1.4(0.2)$ & $1.1(0.4)$ \\
Rapeseed oil & $14.4(4.7)^{\star}$ & $6.9(1.2)^{\star}$ & $3.8(1.2)$ & $23.8(2.4)^{\star}$ \\
Tung oil & $7.3(0.4)$ & $1.3(0.3)$ & $0.7(0.6)$ & $22.0(4.1)$ \\
Linseed oil & $9.6(4.9)^{\star}$ & $0.6(0,2)^{\star}$ & $3.0(0.7)$ & $10.4(2.6)$ \\
Linseed oil and & $2.3(0.1)$ & $2.0(0.1)$ & $3.5(0.4)$ & $1.7(0.3)$ \\
Preservative & & & &
\end{tabular}

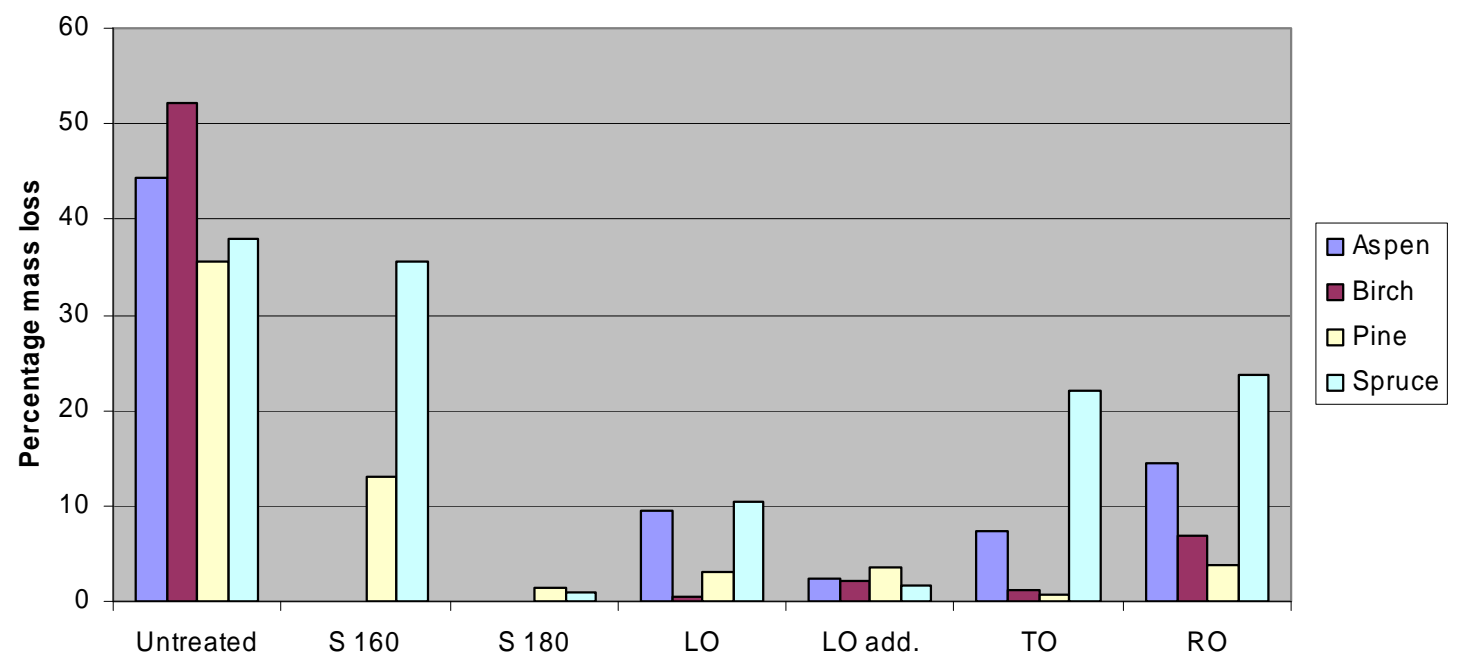

Fig. 6. Mass loss after exposure of wood and thermally modified (TM) wood to brown rot (Coniophora puteana) according to EN 113 ( ${ }^{*}$ exudation of oil was observed in test); S160, S180 (TM in saturated steam at $160^{\circ} \mathrm{C}$ and $180^{\circ} \mathrm{C}$, respectively), LO (TM in linseed oil and soaking), LO add (TM in linseed oil including preservative and soaking), TO (TM in Tung oil and soaking), and $\mathrm{RO}$ (TM in rapeseed oil and soaking). 


\section{CONCLUSIONS}

1. Results reported in this paper show that it is possible to influence material properties such as durability against brown rot fungi and cycling climate by choice of type and extent of thermal modification of wood as well as the wood species and tissue type.

2. Thermally modified aspen was found to be a suitable wood species that did not show any formation of cracks when used in climate conditions resembling those occurring in Northern Scandinavia and was quite resistant to brown rot fungi.

\section{ACKNOWLEDGMENTS}

The authors are grateful for the support of Kempestiftelserna and EU, objective 2. Many thanks to Nasko Terziev at Swedish agricultural university (SLU) for EN 113 tests.

\section{REFERENCES CITED}

Alén, R., Kotilainen, R., and Zaman, A. (2002). "Thermochemical behaviour of Norway spruce (Picea Abies) at 180 180-225 ${ }^{\circ}$ C,” Wood Sci. Technol. 36, 163-171.

Boonstra, M. J., Tjeerdsma, B. F., and Groeneveld, H. A. C. (1998). “Thermal modification of non-durable wood species. 1. The Plato technology: Thermal modification of wood,” IRG/WP 98-40123, IRG Secretariat, Stockholm, Sweden.

Burmester, A. (1973). "Effect of heat-pressure-treatment of semi-dry wood on its dimensional stability,” Holz Roh- Werkstoff 31(6), 237-243.

Dagbro, O., Torniainen, P., Morén, T., and Karlsson (2010). “Comparison of colour responses from heat treated wood by WTT Process and ThermoWood® Process,” Wood Mater. Sci. Eng. 5, 211-219.

Dirol, D., and Guyonnet, R. (1993). "The improvement of wood durability by retification process,” The International Research Group on Wood Preservation, IRG/WP 9340015, IRG Secretariat, Stockholm, Sweden.

Dubey, M. K., (2010). “Improvements in stability, durability and mechanical properties of radiate pine wood after heat-treatment in a vegetable oil,” Master thesis, Forestry at the University of Canterbury, Christchurch, New Zealand.

EN 335-1 (1992). "Hazard classes of wood and wood-based products against biological attack," Classification of hazard classes.

EN 113 (1996). "Wood preservatives -Test method for determining the protective effectiveness against wood destroying basidiomycetes - determination of toxic values.”

Fengel, D., and Wegener (1989). Wood. Chemistry, Ultrastructure, Reactions, Walter de Gruyter, Berlin, New York.

Giebeler, E. (1983) "Dimensional stabilization of wood by moisture-heat-pressuretreatment,” Holz Roh- Werkstoff 41, 87-94. 
Grenier, D., Baillères, H., Méot, J. M., Langbour, P., and Lanvin, J. D. (2003). “Oil absorption during oleothermic treatment of wood,” In: The First European Conference on Wood Modification ECWM 2003, 3-4 April, Ghent, Belgium.

Guner, Ö. (2009). "Evaluation of wood and aluminium stickers and their stains on heat treated spruce boards-Influence of quality and cost,” Master thesis, Department of Skellefteå Campus, Luleå University of Technology, Sweden.

Hietala, S., Maunu, S. L., Sundholm, F., Jämsä, S., and Viitaniemi, P. (2002). "Structure of thermally modified wood studied by liquid state NMR measurements," Holzforschung 56, 522-528.

Lide, D. R. (1996). Handbook of Chemistry and Physics, $76^{\text {th }}$ Edition, CRC Press, Boco Raton, USA.

Mayes, D., and Oksanen, O. (2002). ThermoWood Handbook. By: Thermowood, Finnforest, Stora.

Ohnesorge, D., Tausch, A., Krowas, I., Huber, C., Becker, G., and Fink, S. (2009). "Laboratory tests on the natural durability of six different wood species after hygrothermal treatment,” Proceedings of the Fourth European Conference on Wood Modification, 27-29 April, 2009, Stockholm, Sweden.

AOAC International (1984). "Official methods of analysis of AOAC International, Iodine absorption number Wijs method,” AOAC Official Method 28.023, Arlington,

Rapp, A. O., and Sailer, M. (2001). "Oil heat treatment of wood in Germany - State of the art,” In: Review on Heat Treatments of Wood, COST Action E22, Environmental Optimisation of Wood Protection, Proceedings of the special seminar held in France, on 9 February 2001, Forestry and Forestry Products, 9 February, Antibes, France.

Sehlstedt-Persson, S. M. B. (1995). "High-temperature drying of Scots pine. A comparison between HT- and LT-drying," Holz Roh- Werkstoff 53, 95-99.

Sehlstedt-Persson, M., Johansson, D., and Morén, T. (2006). “Absorption of liquid water in pine, birch and spruce and the effect of heat treatment on the microstructure," Proceedings of the 5th IUFRO Symposium Wood Structure and Properties, Zvolen, Slovakia, 251-255.

Sivonen, H., Maunu, S. L., Sundholm, F., Jämsä, S., and Viitaniemi P. (2002). "Magnetic resonance studies on thermally modified wood,” Holzforschung 56, 648-654.

Stamm, A. J. (1964). Wood and Cellulose Science, Ronald Press, New York, USA.

Syrjänen, T, and Kangas, E. (2000). "Heat treated timber in Finland,” The International Research Group on Wood Preservation, IRG/WP 00-40158, IRG Secretariat, Stockholm, Sweden.

Theander, O., Bjurman, J., and Boutelje, J. B. (1993). “Increase in the content of lowmolecular carbohydrates at lumber surfaces during drying and correlations with nitrogen content, yellowing and mould growth,” Wood Sci. Technol. 27, 381-389.

Tiemann, H. D. (1915). "The effect of different methods of drying on the strength of wood,” Lumber World Review 28(7), 19-20.

Tjeerdsma, B. F., Boonstra, M., Pizzi, A., Tekely, P., and Militz, H. (1998).

"Characterisation of thermally modified wood: Molecular reasons for wood performance improvement,” Holz Roh- Werkstoff 56, 149-153. 
Tjeerdsma, B. F., and Militz, H. (2005). “Chemical changes in hydrothermal treated wood: FTIR analysis of combined hydrothermal and dry heat-treated wood,” Holz Roh- Werkstoff 63, 102-111.

Ulvcrona, T., Lindberg, H., and Bergström, U. (2006) “Impregnation of Norway spruce (Picea abies L. Karst.) wood by hydrophobic oil and dispersion patterns in different tissues," Forestry 79(1), 123-134.

Wang, J. (2007). "Initiating evaluation of thermal-oil treatment for post-MPB lodgepole pine” Forintek Canada Corp., Vancouver BC, Canada.

Wang, J. Y., and Cooper, P. A. (2005). "Effect of oil type, temperature and time on moisture properties of hot oil-treated wood," Holz Roh- Werkstoff 63, 417-422.

Wikberg, H., and Maunu, S. (2004). "Characterisation of thermally modified hard- and softwoods by 13C CPMAS NMR,” Carbohydr. Polym. 58, 461-466.

Windeisen, E., Strobel, C., and Wegener, G. (2007). "Chemical changes during the production of thermo-treated beech wood,” Wood Sci. Technol. 41, 523-536.

Article submitted: August 20, 2010; Peer review completed: September 13, 2010;

Revised version received: December 7, 2010; Accepted: December 9, 2010; Published:

December 11, 2010. 